MILENA DŽEVERDANOVIĆ-PEJOVIĆ, Ph.D.

E-mail: milenadz@ucg.ac.me

University of Montenegro

Faculty of Maritime Studies Kotor

Dobrota 36, 85330 Kotor, Montenegro
Education in Traffic and Transport Original Scientific Paper Submitted: 18 Jan. 2020 Accepted: 13 July 2020

\title{
DISCOURSE OF LOGISTICS AND TRANSPORTATION
}

\begin{abstract}
The discourse approach for analysing various specified genres and professional discourse communities has increased in recent decades. Globalisation and synergy of disciplines opened up space for the interdisciplinary studies. The analysis of the specialized discourses enables to reveal the peculiarities and dominant concepts of the professional fields. With this in mind, this paper aims to examine the features of discourse employed in the research articles and publications about transport and logistics. The paper analyses the structural and qualitative aspect of the discourse of logistics and transportation. Based on the move/steps model, the main components of the research article in this discourse domain are found. Then, the analysis is focused on the discourse indicators that differ logistics and transportation genres from other academic genres. The changes in the scope and interest domain of logistics are worth "tracking and tracing" from a discursive aspect. The research is carried out on the material compiled of the academic research articles on logistics and transportation, referential resources in the field, and logistic dictionaries. The analysis shows that changes in logistics and transportation correlate with discourse changes. On a diachronic level, many concepts are replaced by new ones containing new approaches and dimensions in logistics. The analysis conducted in this paper brings new insight to both disciplines, logistics and linguistics.
\end{abstract}

\section{KEY WORDS}

logistics and transportation; discourse; logistic concepts; research articles;

\section{INTRODUCTION}

The majority of definitions of logistics relates to the transportation and movement "from one point to another", warehousing, production, handling, storing of goods in an appropriate place. These activities imply control over the movement of goods and the complex administrative procedures such as processing orders $[1,2]$. Simply put, the main ideas in these definitions are of movement and flow. In that sense, we meet with a few most important phrases such as supply and demand, shipping of goods, the cost of transport, the choice of carrier, freight, shipping and transportation documents, intermodal transport, planning and optimization, the logistic chain.

However, all definitions need constant revisions as the dynamics of social and institutional changes calls for the new concepts and terminology. Innovations in logistics, enhanced performance and extension of services, have included the concept of integration, networking and rise of integrated systems and logistics networks [3].

From the middle of the $20^{\text {th }}$ century, the inevitable emerging concepts in logistics have included the concepts of planning, effective scheduling, and organisational aspect. The changing environment and innovations in logistics imposed the need to turn towards the technological innovations. Logistics has, to a large extent, converted from being empirical to being analytical. Finally, the interdisciplinary nature of logistics is seen in its connectivity with technology, economics, mathematical theories, statistics, and engineering. The methods and strategies of the modern logistics have heavily relied on the autonomous processes, the Internet-based platforms, virtual centralization and other e-performance domain [4].

These changes in a modern logistics and transportation domain and the rise of the Internet-accompanied technologies and devices, left a trace in logistics and transportation discourse.

Some concepts in logistics have become outdated, while some concepts have evolved or broadened their meaning, to include contemporary activities and methods. The example of the widening of the meaning is the term network: in a traditional view logistics network planning is defined as a system of planning and distribution process. The second 
meaning of the term network denotes a system of electronic data exchange and a link between computer users [5].

Another illustrative example is the broadening of the meaning of the term platform. The term platform initially meant a physical means of transport, either a simple wooden wheel type at the wharves, or a type of truck meant for cargo handling. Electronic platforms improved the performance of logistic services and mitigated the possibility of error [6]. Nowadays, the term platform in logistics has become very much employed word brought from the information technology domain. It denotes a variety of evolving electronic platforms (Big data platform, IoT platform, the fog computing platform), designed for various purposes (scheduling, tracking, mapping).

Besides, the changes in the logistic scope have not reflected only on the specialized logistic vocabulary, but also on the type of logistic genres. The rise of globalization and digitalization spurred the rise of the electronic genres that save time and make the documents more accessible. The example of this is a tendency towards replacing physical printing and issuing of documents. For example, paperless or electronic bills of lading $(\mathrm{eB} / \mathrm{Ls})$ save time and enable easier data handling.

As seen, the above changes in the domain of logistics and transportation methods, have manifested themselves in the discourse of this vast professional community. Simply put, dynamics of changes has been reflected not only on terminology, but also on the genres that the logistic stakeholders use.

In view of this, the paper aims to point to a reciprocal relationship between the logistic discourse and the logistic environment. To show this interrelation, we used the academic research articles and books about logistics and transportation, as the most referential corpus in this field.

As said, the general concept of transportation in physical space has become complemented with a crucial aspect of data transfer in the cyberspace. The influence of communication technologies put into focus the Complex Event Processing (CEP) as a part of the Internet of Things (IoT), Big Data, all of which are related to data transformation, storage, analysis, and reporting/presentation [6].

Our attempt in this paper is to present how traditional concepts and the new trends in logistics and transportation manifest themselves in a discourse of research articles. More precisely, we try to illustrate how the "external" changes, in the context of globalization and digitalization, reflect on the language that members of the scientific logistic community use.

We are well aware that the paper tries to connect two divergent disciplines, which makes the research in this paper more demanding. Conclusions reached in this paper may benefit the logistic researchers and discourse researchers. The former may focus on how discourse conveys fundamental changes and transitions in the vast and complex domain of logistics and transportation. The latter may benefit from observing how this specific discourse constitutes a logistic professional community.

\section{MEANING OF THE TERM DISCOURSE}

For the sake of better comprehension of the term discourse in this paper, it should be regarded as a social-dependent and interactive category that reflects our knowledge about the world. Discourse is recognized by the recurrent discourse features expressed either through modes of communication, register or style [7]. Genres characterize discourse in each professional setting and are a means for obtaining a specific communicative goal. According to Bhatia, genres of each discourse community have their generic form or typical formation. Genres are dynamic categories, and they are shaped by social changes in language [8].

Many genres have set in place and many have lost their importance in the logistic setting. For instance, the rise of e-logistics performance has benefited from e-documents and has replaced tons of hardcopy papers and files. Data storage, the rise in cyberspace and IoT, on the other hand, have greatly facilitated transfer and accessibility of the electronic documents in digital documentation centres.

Changes in logistics have speeded up the pace at which the new terms have been created and applied by the professional users. Logistics and transportation discourse, being international, connects various stakeholders in communication activities taking place within national borders, or more frequently, on a cross-border level. Members of the latter discourse communities speak different languages, and they must adapt to a changing discourse environment and use discourse in their professional assignments. This means that warehouse workers need to know a limited technical vocabulary within the scope of their daily work. The planners and managers at the 
terminal offices should have a higher, verbal and discursive competence in English. As English is the main language of trade, transportation, the cultural issues in communication must be borne in mind as well. This involves cross-border trade and translation of documentation. It was found that the language factor contributes to misunderstanding in communication between exporters when crossing international borders [9].

Further, as regards the nature of the intermodal transport, clear communication between the public infrastructure owner and the private operator is essential. It requires an excellent verbal communication regarding performance goals, conditions of the contract, negotiations discourse and rhetorical skills. Last but not least, the academic research articles on logistics and transportation present the most referential domain for the analysis of discourse changes. By presenting the latest facts, assumptions, discussions, the researchers employ the new concepts and terminology embedded in the current logistics and transportation world.

The fact is that the logistics has become interdisciplinary. This mainly refers to the rising influence of the economy, information technology, electronics, engineering, and higher demands in the logistic services. The new words coined from the IT domain are cyber transportation logistics, information logistics, and many derived from the SBS (Software-Based Services).

Sometimes, many words from the logistic discourse are used to refer to the same concept. Even the logistic experts cannot set the boundaries between the new terms or find the right term "for the multitude of logistic subjects" [3].

Compared to past decades, the discourse of logistics has broadened its scope and has been enriched with many depictive, idiomatic and figurative expressions. What used to be a "simple" and a generic term for a vehicle such as a lorry has nowadays turned into piggy back, trailer train, boggy or dolly. Some logistic terms may sound puzzling and bewildering and cannot be found in general language [5].

Also, the new concepts brought by the interdisciplinary logistic environment are integrated, autonomous, smart, cooperative, comprehensive, electronic (e-). All of these relate to the new era in logistic infrastructure technologies, as "growing demand of mobility of the twenty-first century challenges researchers from various fields to design and develop more efficient traffic and transportation systems, including control devices, techniques to optimize the existing network, and information systems" [10].

\section{DATAAND METHODOLOGY}

In this paper, the analysed corpus comprises the research articles and books on logistics and transportation. We used the text search option to establish the most frequent words and phrases prevailing in the discourse of logistics.

The paper consists of two parts. The first one focuses on the identification of the current structural sections of the research articles on logistics and transportation, based on the moves/steps model provided by Swales. The examples then explicate the discursive intention of the established moves and steps in the texts.

Table 1 -Details of the corpus

\begin{tabular}{||l|c|c||}
\hline Corpus source & $\begin{array}{c}\text { Academic } \\
\text { research } \\
\text { articles }\end{array}$ & $\begin{array}{c}\text { Logistics and } \\
\text { transportation } \\
\text { books }\end{array}$ \\
\hline \hline Word count & 31,228 & 125,258 \\
\hline Number of units & 25 & 8 \\
\hline Number of pages & 480 & 3,240 \\
\hline
\end{tabular}

The second part of the paper is focused on the establishment of the concepts in the contemporary discourse of logistics and transportation. This is achieved by highlighting the most frequent words and phrases, the formation of the phrasal words and idioms prevailing in the texts. Of particular relevance are the specialist words, abbreviations and acronyms characteristic of a logistic discourse.

The main hypotheses in this paper are related to recognizing how changes in the logistics and transportation setting reflect on the discourse, more precisely, on the academic discourse texts.

In light of this, the first hypothesis is that the structural or surface structure of the academic research texts on logistics and transportation will comply with the prescribed norms of the academic text writing. Nevertheless, as each professional discourse has its recognizable communicative patterns, it is expected that discursive determinants of the specialized logistic texts will reveal basic logistics concepts (concepts of movement, flow, transport, transfer).

It is expected that the discourse of logistics contains a specific repertoire of technical terms. It will be argued that the dynamics of changes in 
logistics has brought many changes from a diachronic perspective, which is traced in the academic logistic discourse. The second hypothesis, therefore, tends to show how these changes are relevant to the complex logistics and transportation setting.

\section{RESEARCH RESULTS}

The first part of the paper refers to the analysis of the structural organization of the research articles and its components.

As expected, the structure of the academic texts on the transportation and logistics complies with the academic rules on the research text writing. The analysis of the main components of the surface structure is based on the moves and steps model provided by Swales. Moves are distinct thematic sections of the research articles carrying the author's main communicative aim. Steps are sentences or shorter paragraphs within Moves that support and develop the authors' arguments. After the analysis of 25 research articles about the logistics and transportation from 2010 to 2020, the major moves/steps found in the texts are:

Move 1: Background/Introduction

Step 1: Literature review: stating a gap

Move 2: Redefinition of the concept

Move 3: Conclusion

Step 1: Future research

\section{Move 1: Background/Introduction}

Move 1 tends to set the prominence of the topic in question by emphasizing the role of logistics and transportation since the earliest times. Usually, Move 1 contains long causative sentences, and the authors emphasize the dynamic changes in the evolution of logistics. This is achieved by the use of the words growth, nationalization, globalization, performance and competitiveness, integration, planning, organization. The notion of growth on a global level is found in Kumar [11]:

1) "This research topic is gaining popularity globally both to drive performance improvements and to benefit from new insights".

2) "In the present scenario with the nationalization and globalization, the importance of logistics management has been growing in various areas".

3) "In the recent decade, the management of logistic activities has become one of the valuable ways to gain competitive advantage and to enhance organizational performance".
Move 1 comprises Step 1 Literature review: stating a gap, and is a subtle discursive introduction for the redefinition of the knowledge of logistics in Move 2. The main communicative effect of Step 1 (Move 1) is to provide up-to-date articles and books on the problematics of logistics and to indicate recent trends in the logistic environment. This literature gap is introduced by the connectors however, but, still:

4) "However, current literature lacks a clear, complete, and commonly accepted definition of synchromodal logistics and its features. In our definition, synchromodality is the provision of efficient, reliable, flexible, and sustainable services through the coordination and cooperation of stakeholders and the synchronization of operations within one or more supply chains" [12]. In order to support their idea for the need to revaluate the concept of logistics given the emerging trends and technologies, the authors use the trinomials, typical of a persuasive academic discourse:

5) "identity novel research questions, and to examine the conditions under which these emerging technologies can create economic, environmental, and/or social value." [13].

Sentences applying the three words patterns are found in the research articles of recent date (from 2015 onward):

6) "We demonstrate the individual aspect of the programming model in great detail, so that appropriate application solutions, methods of implementation, and other key choices can be built, made, and evaluated. Finally, we identify the open challenges, opportunities, and trends in the IoT platforms" [6].

7) "Computing, storing, and networking are the building blocks in both computing systems [6]"

\section{Move 2: Redefinition of the concept}

Move 2 provides new ideas about logistics and transportation, and it is the most extended section of the research articles where researchers present the new concepts. It is introduced by a rhetorically effective sentence at the beginning of the first paragraph of the Introduction, and is often preceded by a curious subtitle such as Varying terminologies and definitions, Revolution of Logistics, Emerging issues in logistics, Logistics: A diamond in the rough, Hot Issues.

To introduce the reader with the new and emerging ideas, the authors use the causative connectors: 
8) Due to extensive research ranges in operations management of logistics and supply chain management, we cannot possibly make a comprehensive review in one paper. In this section, we point out several of the most important issues and hot topics in recent research, which draws great attention from both academy and industry" [14].

The idea of a holistic and comprehensive approach is commonly employed in Move 2, which infers to the novelties in transportation and logistics and calls for the integration and synergy of all the involved parties:

9) "Manufacturers, logistics, suppliers, and retailers should develop a holistic and comprehensive approach to add value to their customers and services" [15].

10) This article investigates the correlation between Big Data and IoT systematically and introduces a comprehensive relationship model to synergize IoT and Big [6].

Move 2 also lays down the most critical ideas established in the articles, and these are: movement, flow, transport and transfer where movement is taken as the broadest term (Figure 1).

The concept of movement

Figure 1 - Graphical presentation of movement in logistics [1]

It must be well noted that the terms transfer and transportation, which have been often used in the same context (to move someone or something from one place to another), have been differentiated in the recent research. Thus, the term transportation refers to the means of transportation, physical movement of goods, while the term traffic refers to data.

11) "Heterogeneity of data sources: given the heterogeneity and diversity of IoT devices, GPS signals are generated from different GPS-enabled devices equipped on various means of transportation such as buses, trucks, taxis, and mobile users on cars or motorcycles. Each means of transportation has different traveling behaviors, rate of noises, and quality of data" [25].

Also, the concept of movement found in older publications about logistics and transportation has become complemented with the term connectivity, an inevitable component in a digital world of the emerging platforms and smart devices (Figure 2).
Thus, an inevitable info-communicative aspect of the present and future logistic dimension has been highlighted.

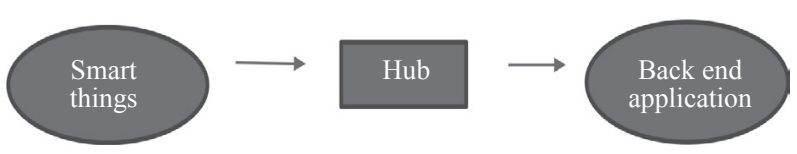

Figure 2 - The concept of devices connectivity

As already mentioned, the frequency of the usage of a particular word helps to comprehend the dominant concepts better. For this purpose, we chose four books on logistics (dating from 2003 to 2019). These are:

- Waters, 2003 [9];

- Daganzo, 2005 [16];

- Monios and Bergqvist, 2017 [2];

- Bhattacharya et al. 2019 [6].

The frequency of the selected words is shown in numerical values on the right side in Table 2.

In order to establish the most frequent words, the texts were first read. After that, the selected words were typed using the search option available in the electronic texts. The occurrence of the most frequent words is automatically highlighted throughout the document.

Table 2 -Occurrence of the most frequent words in the logistic texts

\begin{tabular}{|l|c|c|c|c||}
\hline \multirow{2}{*}{ The searched words } & \multicolumn{4}{|c|}{ Frequency in numbers (book source) } \\
\cline { 2 - 5 } & {$[9]$} & {$[6]$} & {$[16]$} & {$[2]$} \\
\hline \hline Flow & 11 & 105 & 251 & 4 \\
\hline Globalization & 129 & 127 & 20 & 11 \\
\hline Transportation & 120 & 97 & 5 & 24 \\
\hline Movement & 85 & 32 & 30 & 77 \\
\hline Integrated & 46 & 16 & 21 & 45 \\
\hline Environmental & 19 & 21 & 46 & 2 \\
\hline International & 66 & 111 & 11 & 34 \\
\hline Intermodal & 16 & 17 & 9 & 9 \\
\hline Platform & 24 & 145 & 23 & 4 \\
\hline Connectivity & 46 & 259 & 45 & 57 \\
\hline Traffic & 54 & 258 & 25 & 22 \\
\hline Network & 34 & 625 & 242 & 56 \\
\hline Autonomous & 1 & 225 & 0 & 450 \\
\hline Communications & 36 & 450 & 0 & 328 \\
\hline Smart & 0 & 432 & 0 & 467 \\
\hline Digital & 0 & 40 & 0 & 0 \\
\hline
\end{tabular}


The figures presented in Table 2 indicate that the publications of earlier date contain the traditional logistics and transportation discourse terms such as (flow, globalization, movement, integrated, environmental, transportation). For example, it is worth noting that the word autonomous does not appear in the logistic publication issued in 2006, and it appears once in a publication from 2003. The same is with the word platform. However, the word network is used in older publications whenever a reference is made to physical context (logistic network, transport network, intermodal network). In recent publications, the term network [6] is exploited when reference is made to communications and data transfer (network space, network communications, network delay, interruptions, transit network).

In addition, up-to-date books use the contemporary logistics concepts such as autonomous environment and platforms in their contents. This confirms the view that discourse and genres "are hospitable to a measure of difference that are most likely to adapt to changes in the context within which they operate" [17].

\section{Move 3: Conclusion}

Move 3 in the research articles about logistics and transportation is a summary of previous sections in the article. The peculiarity of this section is that the authors point out that cooperation and synchronization in logistics are visible on the global level [11]. Also, they use the opportunity to put the accent on the future research (Step 1) and the models of research. As regards the final assumptions, the authors very much use the modal can [11]:

12) Finally, the current research study is opening new ways of research in the field of logistics [4].

13) This research study can be improved by including other performance indicators such as electronic tracking system of logistic goods and delivery time. However, the user acceptance is important which can be used as moderator in the current research framework [4].

The second part of the research in this paper focuses on the prevailing discourse belonging to the transportation and logistics domain.

The two-word expressions are phrases often found in the commercial, merchant or legal discourse and have a useful rhetorical effect. Binomials are simply the pairs of words linked by the conjunction and. They are very popular in logistic glossaries. In general language, binomials are present in each language and are easy to memorize. Most known examples from the everyday language are "safe and sound", "loud and clear".

The following pairs are found in the logistic dictionaries $[5,18,19]$. They may be composed of nouns as in tracking and tracing, picks-up and deliveries, challenge and response, hire and reward, hub and spoke, incentives and restraints, bus and rail, As and Ds (applications and decisions). However, the examples with the pairs of verbs have become particularly popular in the logistic discourse. These are: pick and pack, wagon and drag, and hail and ride.

\subsection{From in-bound logistics to e-logistics}

As already mentioned in the paper, changes that affected contemporary logistics can be tracked in the discourse, particularly on the vocabulary level [20].

It was found that a logistic discourse, as each professional discourse, contains the specific rules for the production of new terms. Hyphening is a popular way to produce a new term by stringing two words of similar meaning. A hyphen shows that there is a close semantic connection between words making the unit. Otherwise, they might be interpreted as separated words. Hyphenated words are usually used as attributives describing closer the noun as in a track-laying vehicle, door-to-door service, make-or-buy decision, device-to-cloud communication, swan-neck trailer, wall-to-wall inventory or machine-to-machine interface, device-to-device discovery, fog-to-fog link [6]. However, the fact is that specialized language terms are rather quickly invented and sometimes break the standardized norms pertaining to the formation of new words.

The commonly employed hyphenated words are: 1) Noun plus verb: plan-to-check, cost-to-serve, time-to-market, duty-to-stop;

2) Verb plus verb: make-to-order, make-to-stock, pick-to-clear, explode-to-deduct, pick-and-pass;

3) Adjectiveplusverb:open-to-buy,open-to-receive, direct-to-store.

Many compounds in a logistic discourse that imply movement within the interior of the object or space are in-and-out, last-in first-out, in-transit inventory, in-store implementation, inbound logistics, in-cab computer, in-network caching/processing. Other prefixes used to denote the movement or the 
activities performed outside the company or facility are outgate, outsourcing, outpartnering, and outstations.

A shift to e-logistics and e-performance in logistics and transportation is found in over 30 words containing the prefix $-e$, denoting electronic environment performance. The most representative examples are e-business, e-commerce, e-learning, e-fulfilment, e-shopping, e-tailing, e-science, e-engineering, e-government (service), e-health (gateway), e-medicine, and e-document.

\subsection{The concept of life in logistics and transportation}

There is no doubt that many words and phrases in a discourse of logistics and transportation are very illustrative and depictive, although this discourse is mainly categorized as a technical one. The figurative use of certain words make them sound aesthetically pleasing. That is the feature of many professional and specialized discourses. Productivity in creating logistic words requires specialist knowledge, effort and competence [5]. The pace of producing new words in a discourse of logistics and transportation is such that the emergence of new words is difficult to follow.

The new words are mainly generated by the stakeholders engaged in the haulage and road transportation. The words from this discourse domain refer to slang, abbreviations, metaphors and jargon [5].

The concept of the longevity of the product or its lifetime is commonly used in logistic discourse. There is time predicted for products to be kept instore, which is known as shelf-life or life-store. In addition, the life-cycle analysis deals with penalties and benefits of the product, while the life cycle assessment concerns the assessment of the product's life. Also, the concept of durability is contained in the terms total life cost and lifed item. Likewise, the concept of "end of a product's life" is given in endof-life inventory referring to planning of activities and the end of their life cycle. In a discourse of the modern internet technologies, lifetime goes with the terms network, battery (as in prolongation of a battery or network lifetime).

Many human behaviour-related activities are prescribed to the work of machines, which makes this discourse more illustrative [21]. Such examples are kissing, denoting pairs of tyres that are touching. References to the human body or activities prescribed to humans are also found in the examples broken heart or out of mind. As regards body parts found in a discourse of logistic, they often related to vehicles structure as in compactor body, swap body. Leg refers to a part of the voyage while on landing leg denotes the trailer structure. Physical reference to the neck as a turning part of a human body is found in the example swan neck trailer. Likewise, physical obstruction in the human neck is associated with the bottleneck, denoting congestion as in bandwidth bottleneck, or parking bottleneck.

\subsection{CLO, BD or IoT?}

Abbreviations and acronyms are a common feature of technical discourses. As regards the examples from the logistics and transportation, most of them are standardized and logistic-specific. The others are invented at a rapid pace by logistics and transportation practitioners and in most cases without any language rule [22].

Some abbreviations are interdisciplinary and also found in a discourse of trade and commerce. These are standardized like $\mathrm{B} / \mathrm{L}$, eB/L (Bill of Lading, electronic bill of lading), DP (documents against payment), $\mathrm{C} / \mathrm{P}$ (Charter Party), and $\mathrm{C} / \mathrm{N}$ (Consignment Note). Examples of more recent date are mainly standardized abbreviations made of the initial letter of the word. The examples are: LSP (Logistics Service Provider), FCL (Full Container Load), JIT (Just in Time), DOG (Daily Order Generation), BOO (Build, Own and Operate). Some forms present a combination of numbers and letters as in 3PL and 4PL (third-party logistics, four-party logistics), B2B (business to business) or P2P (peerto-peer). In some cases, the abbreviation presents a whole word containing a single syllabus of the words it refers to, as in $d o c$ (document) or ad (advertisement).

It was found that longer abbreviations (containing up to five letters) are common in the logistic texts. These are mainly acronyms made of the first letters of the words as in DiPTAC (Disabled Persons' Transport Advisory Committee) or such as NVOCC (Non-Vessel Operating Common Carrier). In some cases, abbreviations are a combination of initial letters and the syllable of the word as in BACAT (barge-aboard-catamaran).

The significant number of acronyms and abbreviations that entered the logistic discourse is a result of the application of IT knowledge in modern logistics and transportation. Some illustrative examples 
are CLO (cloud), IoT (Internet of Technology), BD (Big Data), CC (Cloud computing), EC (Edge Computing), DAHP (Database Active, Human Passive), and many examples referring to the intertwining of autonomous systems in the real-world situations.

Abbreviations in a discourse of logistics are also subject to expansion of meaning. This can be illustrated by the primary meaning of the abbreviation $P P C$ (Production, Planning and Control). The extension of meaning can be explained by the rise of information technologies and software, so that the PPC denotes the actual task of planning control, and the software used to support these operations. These two abbreviations are not interchangeable [23], and each is interpreted within its own (logistic) context.

\section{CONCLUSION}

The findings presented in this paper identify the peculiar discourse patterns of the research articles about logistics and transportation, as most representative of the changes and novelties in this field.

It is argued at the beginning of this paper that the interdisciplinary nature of logistics and transportation has to a great extent reshaped the discourse practices used among the logistics and transportation stakeholders. What was originally a technical discourse, nowadays has been influenced by various disciplines. The research presented in the paper, therefore, presents a contribution to an interdisciplinary research, particularly in targeting different perceptions from a traditional to contemporary logistics.

In doing so, the paper offers a view of the structural organization of the research articles about logistics and transportation and the analysis of its characteristic parts. It was found that the logistic researchers apply the traditional norms of the academic writing (background, literature review, redefinition of the concept, conclusion, and future research). As expected, the differences between the logistic and other research articles are more evident on the level of terminology. The research articles are characterized by the long sentences and groupings of three words (globalization, nationalization and growth; economic, environmental and social). Also, as the logistic trends evolve, there is a notable rise of the new concepts such as holistic, comprehensive, and integrated.

The impact of digitalization and the Internet environment has greatly changed the face of the logistic research and domain. Some words have widened their meaning (such as transport, platform). In addition, there is a notable tendency toward the formation of the new words, abbreviations and acronyms, given the rise of the new transportation means and self-autonomous systems. Also, it is noteworthy that the logistic discourse has been characterized by the concepts which refer to human life or human-related activities.

We hope that the topic investigated in this paper will spur interest for further investigations of this kind, as we find that the logistic discourse has been inexplicably underexplored. One of the contributions of this paper is to show how changes in logistics and transportation domain can be interpreted from the social or discourse approach. Language or discourse is inevitable characteristic of communication for bridging gaps in logistic communication, and therefore a discourse approach brings new insights into the interdisciplinary considerations in this field.

That said, we find that there are many valuable domains of logistics and transportation worth exploring from a discursive aspect in future research. An interesting field of study would involve the contribution of the statistical programmes in processing large corpora of the specialized texts, which may result in the design of the artificial or limited languages. Such a research may also bring useful results in modelling communicative patterns in the professional discourses and improve understandability of problem specifications [24].

\section{MILENA DŽEVERDANOVIĆ-PEJOVIĆ, Ph.D.}

E-mail: milenadz@ucg.ac.me

Univerzitet Crne Gore, Pomorski fakultet Kotor

Dobrota 36, 85330 Kotor, Crna Gora

\section{DISKURS LOGISTIKE I TRANSPORTA}

\section{APSTRAKT}

Diskursni pristup u analizi raznih specifičnih žanrova i profesionalnih diskursnih zajednica bilježi rast u posljednim decenijama. Globalizacija i sinergija disciplina otvaraju prostor za interdisciplinarna istraživanja. Analiza specijalizovanog diskursa omogućuje da se otkriju specifičnosti i dominantni koncepti iz stručnih domena. Imajući to u vidu, cilj rada je da se utvrde karakteristike diskursa koji se koristi u naučnim radovima i publikacijama iz transporta i logistike. U radu su analizirani strukturalni $i$ kvalitativni aspekti diskursa logistike $i$ transporta. Primjenjujući model analize zasnovan na koracima i stavovima, identifikovane su glavne komponente naučnog rada u ovom diskursnom domenu. Potom 
je fokus analize premješten na diskursne indikatore koji izdvajaju diskurs logistike i transporta u odnosu na druge akademske žanrove. Promjene u području i interesovanjima logistike su vrijedne „praćenja“ sa diskursivnog aspekta. Istraživanje je sprovedeno na korpusu koji čine akademski naučni radovi iz oblasti logistike i transporta, referentni izvori u ovom domenu, kao i rječnici iz oblasti logistike. Analiza pokazuje da promjene u logistici $i$ transportu koreliraju sa promjenama na nivou diskursa. Na dijahronijskom nivou, mnogi koncepti zastarijevaju $i$ bivaju zamijenjeni novim pristupima u logistici. Analiza koja je sprovedena u ovom radu pruža nova saznanja po obje discipline, kako logistiku, tako i lingvistiku.

\section{KLJUČNE RIJEČI}

logistika i transport; diskurs; logistički koncepti; naučni radovi;

\section{REFERENCES}

[1] Islam DM, Fabian MJ, Paulus TA, Thomas H, Giuseppe P. Logistics and Supply Chain Management. Research in Transportation Economics. 2013;41(1): 3-16.

[2] Monios J, Bergqvist R. Intermodal Logistics. In: Monios J, Bergqvist R. (eds.) Intermodal Freight Transport and Logistics. London. UK: Francis and Taylor; 2017. p. 169194.

[3] Gudehus T, Kotzab H. Comprehensive Logistics. Second Edition. Hamburg: Springer; 2012.

[4] Nadeem S, Alvi AK, Iqbal J. Performance Indicators of E-Logistic System with Mediating Role of Information and Communication Technology (ICT). Journal of Applied Economics and Business Research. 2018;8(4): 217 228.

[5] Lowe D. The Dictionary of Transport and Logistics. London: Kogan Page; 2009.

[6] Bhattacharya S, Banerjeeand S, Chakraborty C. IoTbased smart transportation system under real-time environment. In: Shahid Khan MU, Samee UK, Zomaya AY, (eds.) Big Data-Enabled Internet of Things. London: The Institution of Engineering; 2019. p. 353-373.

[7] Swales J. Genre Analysis-English in Academic and Research Setting. Cambridge: Cambridge University Press; 1990.

[8] Bhatia V. Analysing Genre-Language Use in Professional Settings. London: Longman; 1993.

[9] Waters D. Logistics: An Introduction to Supply Chain Management. New York: Palgrave Macmillan; 2003.

[10] Arango Serna MD, Serna Uran CA, Alvarez Uribe KC. Collaborative autonomous systems in models of urban logistics. Dyna. 2012;79(172): 171-179.
[11] Kumar G, Shirisha P. Transportation The Key Player In Logistics Management. Journal of Business Management \& Social Sciences Research. 2014;3(1): 14-20.

[12] Giusti R, et al. Synchromodal logistics: An overview of critical success factors, enabling technologies, and open research issues. Transportation Research Part E. 2019;129: 92-110.

[13] Tang C, Veelenturf L. The strategic role of logistics in the industry 4.0 era. Transportation Research Part E. 2019;129: 1-11.

[14] Xiang L. Operations Management of Logistics and Supply Chain: Issues and Directions. Discrete Dynamics in Nature and Society. 2014;4: 1-7. Available from: doi:10.1155/2014/701938 [Accessed 23 Jan. 2020].

[15] Govindan K, et al. Big data analytics and application for logistics and supply chain management. Transportation Research Part E. 2018;114: 343-349. Available from: doi:10.1016/j.tre.2018.03.011 [Accessed 15 May 2020].

[16] Daganzo FC. Logistics Systems Analysis. New York, Springer; 2005.

[17] Freedman A, Medway P. Locating Genre Studies: Antecedents and Prospects. In: Freedman A, Medway P. (eds.) Genre and the New Rhetoric. London: Francis \& Taylor; 2005; p. 2-20.

[18] Cavinato J. Supply chain and transportation dictionary. $4^{\text {th }}$ edition. Springer New York; 2000.

[19] Supply Chain and Logistics Terms and Glossary. Bellevue, Washington; 2010. Available from: http://www.iwla. com/assets/1/24/2010_Glossary_of_Terms_10.7.11.pdf

[20] Tseng Y, Yue LW, Taylor M. The Role of Transportation in Logistics Chain. Proceedings of the Eastern Asia Society for Transportation Studies. 2005;5: 1657-1672.

[21] Kövecses Z. Metaphor: A Practical Introduction. Oxford University Press; 2010.

[22] Dževerdanović-Pejović M. Some aspects of logistic discourse. RaDMI 2014: Special Session Sustainable Development in Maritime Transportation and Logistics, Conference proceedings, Bar and Kotor, 17-18 November; 2014.

[23] Schönsleben P. Integral Logistic Management: Planning and Control of Comprehensive Supply Chains. New York: A CRC Press Company; 2003.

[24] Luo Z. Service Science and Logistics Informatics: Innovative Perspectives. New York: Information Science Reference; 2010.

[25] Mahmoud E, Shahrestani S, Cheung H. The Internet of Things, New Operability, Management and Security, Challenges. International Journal of Network Security \& Its Applications (IJNSA). 2016;8(2): 85-99. Available from: https://www.aircconline.com/ijnsa/V8N2/8216ijnsa06.pdf [Accessed 16 May 2020]. 